\title{
Development of International Cooperation of Russian Monetary Institutions
}

\author{
Natalia Amosova \\ Financial University under the Government of the Russian Federation \\ Moscow, Russia \\ NAAmosova@fa.ru
}

\author{
Anna Kosobutskaya \\ Voronezh State University \\ Voronezh, Russia \\ anna.rodnina@mail.ru \\ Alexander Lodyshkin \\ Ivanovo State University \\ Ivanovo, Russia \\ lodyshkin@yandex.ru
}

\author{
Natalia Filimonova \\ Vladimir State University \\ Vladimir, Russia \\ natal_f@mail.ru \\ Olga Luskatova \\ Vladimir State University \\ Vladimir, Russia \\ oluskatova@mail.ru
}

\begin{abstract}
Analysis of the present state and perspectives of participation of Russian banking institutions in international monetary relations is carried out in the article. The assumption is made and substantiated that the format of such participation in the current conditions should be changed. The results of the research work performed by the order of the Government of the Russian Federation on "Assessment of the factors of vulnerability of the national bank system of the Russian Federation and its support taking into account efficiency of activities" are presented in the article.
\end{abstract}

Keywords-international monetary relations; multilateral development banks; banking competition; new format; national identity of banking institutions

\section{INTRODUCTION}

Assuming that the challenges of modernity and changes in the global balance of power call for a well-reasoned public policy in the sphere of international finance and the area of international monetary institutions activity, development of a new format of participation of Russian banking institutions in the sphere of international monetary and credit relations is considered to be important. This is only possible if the tasks of the banking institutions in the international sphere, goals of the international cooperation, opportunities and limitations that follow the process are well-defined [1] [2].

The initial general assessment of Bank of Russia's contacts with the IMF, the World Bank Group, other central banks, and multilateral development banks should be given in the article. A role that Russian development banks and Russian commercial banks play in international financial relations should be defined as well [3].
Sweeping changes in global employment and labor specialization, in the structure of economic systems, in people's vision of the capabilities of enginery, in ratio of real and financial sectors of economy, and in vision of the role of banks in economic systems were results of the technological revolution of recent decades. The behavior of all economic processes has changed; they have become less predictable and manageable. The expectations and economic behavior of economic entities have changed also; new forms of competition have emerged; economic and administrative boundaries have become more transparent. State intervention in economy has become very costly and markedly less effective. Relations between real and financial sectors of the economy have changed. Demand and supply in banking market, organizational and institutional composition of banking system and participating competitors, forms and methods of competition have changed radically [4].

It should be pointed out that banks are pressed with functions that are irrelevant to their economic nature, in actual fact they perform government control and other functions. Whereas their new competitors - various multiservice companies, for example social networks, refuse to take on the function. Business independence is a great asset, but it remains the case that the official law enforcement authorities are actually less likely to cope with crime in the financial sector without participation of the financial market institutions.

E. Nabiullina, the Chairman of the Bank of Russia, identified at the International Financial Congress (2016) the following global economic challenges: low rates of world economy growth, request for populism, growth of inequality, transition of the oil market to a new balance with lower 
prices, extended period of quantitative easing in monetary policy of the leading economies, slowdown in Chinese economy [5].

The list seems to be incomplete. For example, the technological revolution provides both new opportunities and challenges. The question of what economic entity acquires the latest technologies presents not only the issue of leadership in the world economy, but also safety concern.

The global challenges of the banking sector are the following: disproportionate regulation; modification of business influenced by new technologies; parallel banking growth. Weak economic dynamics that substantially narrows down potential of banks to have high profitability; remaining access barriers to foreign financial markets; high debt load in sectors that are traditional for bank crediting; presence of weak market players; lack of long-term loans in economy as a result of underdevelopment of collective savings forms; financing of noncompetitive projects in economy and businesses of financial institution owners, are referred by the Bank of Russia to the specific challenges of the Russian financial system [6].

\section{INTERNATIONAL COOPERATION OF BANKS AND BANK TECHNOLOGICAL AND GEO-FINANCIAL COMPETITION IN THE CHANGING WORLD}

Banking competition, including international one, is undergoing major changes. From our point of view, the following should be considered as a headwinds of unrestricted, healthy bank competition in Russia: concentration of capital by large banks; bank number reduction; non-uniform territorial allocation of banks and their resources; local character of banking (credit, deposit, investment, clearing and settlement, currency, trust, consulting) markets.

The ambiguous fact that affiliation with a financial group or with a "family of capital" is far more important than the interest of the state for the majority of banks, influences participation of Russian banking institutions in international monetary and credit relations. Loss of national identity by modern commercial banks is an important factor that also affects character, forms and methods of competition. Many countries do not state it explicitly but choose to use protective and protectionist measures [7].

The period of revolutionary changes in the financial markets has led to a transformation of composition of competition participants, competition groups and competition itself. It demands not only control from the Federal Anti-Monopoly Service, but also management of competition environment and of legal methods of competition. Thus, it is important to monitor attentively not only situation in the domestic banking market, but also external expansion of the banks. Controlled development of bank competition should be considered as a factor of stability, preservation and protection of national interests of the country.

The competition in the international arena becomes multilevel, multicultural, multi-confessional, discernable, in the international arena. Values and so-called behavioral factors play a special role among competition factors. Not only adaptive, but also power model has being actively developed among competitive strategies. Geo-financial competition for some time now has been taking the form of geo-financial war: sequential exclusion of a competing country and its economic entities from world financial flows and markets is evident [8]. One may state that nowadays global competition manifests itself as a geo-financial war [9].

This causes changes in global operations of the Central bank of Russia, Russian development and commercial banks, as well as multilateral development banks.

\section{COOPERATION WITH INTERNATIONAL MONETARY INSTITUTIONS}

A significant deepening of cooperation across the BRICS countries came out of the commitment to equitable positions in international monetary institutions and real extension of cooperation in all spheres. Due in no small way to the efforts of the Bank of Russia in 2015, "The Operational Agreement", stemmed from the BRICS Contingent Reserve Arrangement (2014) was signed. It has been mentioned at BRIC Summit in Ufa on July 8-9, 2015, that two new financial BRIC institutions - New Development Bank and Contingent Reserve Arrangement - started their full-fledge functioning in 2015 [10].

The IMF and BIS membership remains important. A package of reforms of quotas and IMF management system came into operation in January 2016. The International Monetary Fund quota of the Russian Federation increased from 5945.4 to $12,903.7$ million SDRs, and as specified in the New Arrangements to Borrow the maximum amount of credit arrangements of the Russian Federation was reduced from $8,740.8$ to $4,440.9$ million SDRs [11].

Cumulative share of voices of BRICS countries came very close to the blocking share of voices that the US have. It was an important result of the reforms of quotas and IMF management system and an intermediate short-term target. This fact is quite important against the background of recent enaction of the Memorandum in Washington.

The Memorandum "instructs the United States Executive Director of each multilateral development bank and of the International Monetary Fund to vote against and use best efforts to deny all loans to, and all other uses of those institutions' funds that benefit, the governments of Russia for FY 2017", as it increases the influence of the BRICS countries on the decision-making process. The Bank of Russia continues to use regular meetings of central banks governors at the Bank for International Settlements (BIS) to state its attitude on the key priorities of international financial cooperation, such as: the impact of monetary policy of leading developed economies on emerging markets, centralized clearing and sovereign ratings, digital currencies, issues of financial availability and financial literacy.

Joint research with the BIS - "Inflation mechanisms, expectations and monetary policy" and "Legal aspects of 
central banks liquidity provision" - became a concrete manifestation of this cooperation [12].

The Bank of Russia participates in the activities of the Basel Committee on Banking Supervision (BCBN) within the framework of the Group of Banking Supervisors from Central and Eastern Europe of the BCBN. To coordinate the activities of the bodies responsible for supervision over cross-border institutions of banking groups, the Bank of Russia carried on cooperation with supervisors of foreign countries within the supervisory board, in particular, it participated in supervisory boards arranged by the Central Bank of Hungary and the National Bank of the Republic of Kazakhstan.

Despite a difficult political situation, the Bank of Russia undertakes attempts to maintain a professional dialogue with the G20, the Financial Stability Board (SPS) and the International Association of Insurance Supervisors (IAAS). For example, in the context of cooperation with the SPS, the Bank of Russia took part in the preparation of the following reports: controls of insolvency of financial institutions and central counterparties; trends and risks of a parallel banking system; the results of OTC derivatives market reforms; data submission to swap data repositories and report on the results of reformation of financial organization employees' remuneration system. The results of a survey on the topic "Undesirable consequences of introduction of international financial regulation reforms in national financial markets" of the SPS Regional Advisory Group members in the CIS are of interest.

Note to a consultation document on the capital global standards for international insurance groups, including global systemically important insurance companies, were elaborated by the Bank of Russia for IAIS. In 2015 the Russian Federation submitted an application for accession the IAIS Multilateral Memorandum of Understanding on Cooperation and Information Exchange. The Executive Committee of the International Organization of Pension Supervisors approved the application of the Bank of Russia to join this organization as a full-fledged member.

The Council of Heads of the Central (National) Banks of Member States of the Euro-Asian Economic Community was reorganized into the Advisory Board of Central (National) Banks of the Eurasian Economic Union. Concerned agreement was signed at the end of 2015. Any interested financial regulator from the CIS countries can join the Board in view of the termination of the Eurasian Economic Community (EAEC) from 1 January 2015.

As noted in the Annual Report of the Bank of Russia for 2015 , enhancement of regulatory regimes was carried out within the framework of the Consultative Committee on Macroeconomic Policy. The improvements are focused on ensuring economic growth and pursuing systematic macroeconomic policies of the Member States of the Eurasian Economic Union, and cover the following aspects:

- Main directions of the EAES economic development for the period up to 2030 ;
- Principal benchmarks of macroeconomic policy for the biennium and policy instruments;

- Approved list of statistical indicators;

- Agreement on harmonized approaches to the regulation of the currency relations and the adoption of liberalization measures in the EAEC;

- Agreement on the requirements for the implementation of activities in the financial markets;

- Agreement on admission of brokers and dealers of one Eurasian economic union member state to stock exchanges (trade organizers) of other member states;

- Agreement between the EEA member states on cooperation in the field of pension provision;

- Agreement on a free trade area between the EAES and its member states, on the one hand, and the Socialist Republic of Vietnam, on the other hand (signed May 29, 2015).

\section{COOPERATION IN THE BANKING SECTOR BETWEEN RUSSIA AND CHINA AND BETWEEN RUSSIA AND OTHER COUNTRIES}

Bilateral cooperation both with central (national) banks, national financial regulators of foreign states, and in the context of cooperation with intergovernmental commissions with foreign countries, was carried out with many countries, including, and most actively, with China.

Cooperation with the People's Bank of China (PBC) affects the following areas: expansion of settle in national currencies, strengthening the interaction of commercial banks, assistance in bond issue in national currencies on the markets of the two countries, cooperation in payment systems. The Memorandum on Cooperation between the Bank of Russia and the PBC reinforced the priority nature of joint work in these areas. The Memorandum of Understanding between the China Insurance Regulatory Commission and the Central Bank of Russia concerned cooperation in the field of insurance. An arrangement to establish a resident office of the Bank of Russia to the PBC was reached [13].

Bilateral interstate cooperation is conducted with dozens of countries. It is the most active within a framework of intergovernmental commissions with the non-antagonistic countries such as China, India, Vietnam, Iran, Kazakhstan, Egypt, Thailand, Singapore, Indonesia, United Arab Emirates, Cuba, Mongolia, Argentina, and Brazil.

Russian banking system stability and competitiveness can be increased if it will obtain main characteristics stated below [14]. We consider that the following priority tasks should be assigned in order to overcome vulnerabilities, to respond to external challenges and to increase competitiveness of the national financial institutions. They are anti-cybercrime protection, development of a domestic full-fledged quantum cryptography system, and development of standards that will carry out implementation of the 
technology in cooperation with government and commercial entities. Overcoming the technological lag between commercial banks and IT, multiservice companies and digitalization of all business processes are also of great importance. Search for an appropriate way to attract and retain long-term internal resources, including Islamic [15]. Justification and conscious choice of a model of banking system regulation are required. The following should be the main priorities in modern banking system regulation: flexibility and as consequence usage of agile technologies; preventive measures; skillful usage of Big Data opportunities; protection of national economic interests. Development of computer literacy of the state, public and business agents against the background of banking "digitalization" is important. Forming a digital banking business ecosystem in Russia is essential.

\section{CONCLUSION}

International banking cooperation and banking competition is undergoing a period of profound transformation.

Cooperative relationships between states and banking institutions are much weaker than competitive relations.

In our opinion, to achieve the desired parameters of international cooperation and desired degree of competitiveness of Russian monetary institutions in the longterm, the following on the part of institutions that exert a great influence over its development is required:

- Transformation of the national banking system and changes in the format of participation of banking institutions in international monetary affairs require development of legal and regulatory environment.

- An economic policy in the banking sector, based on the changed balance of power in the world and new trends of technological, institutional, political development should be developed. This policy would determine quantity, attribute characteristics and composition of institutions entitled to provide banking services in domestic and foreign markets; regulators and areas of their responsibility; clarification of the nature of interaction with international and foreign monetary institutions.

- The Bank of Russia, national development banks and commercial banks should be focused on protection of national economic interests, substantiation of decisions regarding the number and composition of banking institutions.
[3] Bank of Russia, 2016, Annual report of the Bank of Russia, 2015, Moscow: Bank of Russia. Available at http://www.cbr.ru/publ/God/ar_2015.pdf

[4] M.A. Eskindarov, Economic policy of Russia in conditions of global turbulence. The first International Forum of the Financial University // Bulletin of the Financial University. 2014. No. 6 (84). pp. 6-9.

[5] Russian Bankers' Association. 2016. Shorthand report of speech of the Chairman of the Bank of Russia E. Nabiullina at the XXV International financial forum. 30. 06. 2016, Moscow: Russian Bankers' Association. Available at http://arb.ru/b2b/news/stenogramma_vystupleniya_predsedatelya_ban ka_rossii_elviry_nabiullinoy_na_khkhv_-10025259//.

[6] Russian Bankers' Association, 2016. Shorthand report of speech of the Chairman of the Bank of Russia E. Nabiullina at the XXV International financial forum. 30. 06. 2016, Moscow: Russian Bankers' Association. Available at http://arb.ru/b2b/news/stenogramma_vystupleniya_predsedatelya_ban ka_rossii_elviry_nabiullinoy_na_khkhv_-10025259//.

[7] Bank of Russia. 2016. Annual report of the Bank of Russia, 2015, Moscow: Bank of Russia. Available at http://www.cbr.ru/publ/God/ar_2015.pdf

[8] N. Amosova, A. Kosobutskaya., U. Treshevski, A. Lodyshkin, Competitive differentiators of modern Russia money-and-credit institutions / Managing Service, Education and Knowledge Management in the Knowledge Economic Era. 2016. Pp. 191 - 198.

[9] Value4risk. 2016. The new world of geofinancial risk management, or the geography of finance as a risk tool./ URL:http://value4risk.com/world-geofinancial-risk-managementgeography-finance-risk-tool/ .

[10] Bank of Russia, 2016. Annual report of the Bank of Russia, 2015, Moscow: Bank of Russia. Available at http://www.cbr.ru/publ/God/ar_2015.pdf

[11] Work flow chart on development of partner banking in the Russian Federation is approved. Banki.ru. 24.03.2016 Available at http://www.banki.ru/news/lenta/?id=8805336

[12] Russian Bankers' Association, 2016. Shorthand report of speech of the Chairman of the Bank of Russia E. Nabiullina at the XXV International financial forum. 30.06.2016, Moscow: Russian Bankers' Association. Available at http://arb.ru/b2b/news/stenogramma_vystupleniya_predsedatelya_ban ka_rossii_elviry_nabiullinoy_na_khkhv_-10025259/

[13] Work flow chart on development of partner banking in the Russian Federation is approved. Banki.ru. 24.03.2016 Available at http://www.banki.ru/news/lenta/?id=8805336

[14] N. Amosova, A. Kosobutskaya., U. Treshevski, A. Lodyshkin, pp 191 - 198.

[15] Money Maker Group. 2016. An international crowdfunding platform for Muslims was launched In the UK / Available at http://mmgp.ru/showthread.php?t=445835.

\section{REFERENCES}

[1] O.I. Lavrushin, On the improvement of the model for credit relations development / Modern problems of the global economy: from the triumph of liberalism to a new "old" economic science. Materials of the international scientific conference. 2014. Pp. 196-199.

[2] I.V. Larionova, Model of efficiency assessment of regulation in the banking sector / Banking services. 2014, No. 1. Pp. 4-8. 